\title{
BERPARTISIPASI DALAM ACARA MUSRENBANGDES
}

\author{
NURMEILANJ
}

9173770410300

$\underline{\text { nurmeilaniiiii@gmail.com }}$

1. Bentuk Kegiatan

Melakukan musyawarah dengan masyarakat desa Bontocini dalam rangka rencana kerja pemerintah desa tahun 2021 dan daftar usulan RKPD tahun 2022.

2. Lokasi

Rumah kepala desa Bontocini dusun palloli kecamatan rumbia.

3. Hari/Tanggal dan Waktu

Kamis 17 september 2020 jam 09:30 sampai selesai.

4. Peserta yang dilibatkan

- Kepala desa

- Kepala camat rumbia

- Anggota DPR

- Dosen pembimbing

- BAPPEDA

- BABINKAMTIBNAS

- Pegawai dinas pertanian

- BABINSA

- Kepala dusun

- Karang taruna

- Mahasiswa KKLP

- Masyarakat desa Bontocini

5. Alasan diadakannya

Alasan diadakan kegiatan musrenbangdes ini adalah untuk memusyawarahkan perencanaan pembangunan desa tahun 2021 serta mendengarkan usulan masyarakat mengenai pembangunan apa saja yang diperlukan di desa. 
6. Tujuan dan Manfaat

Tujuan dan manfaat diadakannya musrenbangdes adalah untuk menentukan serta memutuskan prioritas kegiatan desa yang akan dilaksanakan tahun mendatang melalui dana swadaya/gotong royong masyarakat desa.

7. Deskripsi Kegiatan

Acara ini dimulai dengan sambutan kepala camat rumbia dan beberapa tamu undangan yang hadir di tempat. Setelah itu, kepala desa Bontocini membuka acara musrenbangdes secara resmi. Kemudian sekretaris desa memaparkan rencana kerja pemerintah desa atau program kerja pemerintah tahun yang akan datang (2021). Setelah itu berdiskusi dengan masyarakat serta menyepakati mengenai urutan prioritas rencana pembangunan desa. 